\title{
New distributional record of Stephania glabra (Roxb.) Miers (Menispermaceae) in Tripura, India and its domestication in Reang Home-Gardens
}

\author{
Dipti Das ${ }^{1}$ and B. K. Datta \\ Plant Taxonomy and Biodiversity Lab., Department of Botany, Tripura University, Suryamaninagar, \\ Tripura West-799022, India \\ ${ }^{1}$ Corresponding author, e-mail: diptiagt1964@gmail.com
}

[Received 10.10.2018; Revised 27.12.2018; Accepted 09.12.2018; Published 31.12.2018]

\begin{abstract}
Stephania glabra (Roxb.) Miers (Menispermaceae) collected from Kanchanpur sub-division of Tripura is reported as new record for the state flora. This plant was collected from wild as well as from Reang tribal home-gardens that indicate this plant has been domesticated in their gardens for its usefulness.
\end{abstract}

Key words: Stephania glabra, Reang tribe, Home Garden, Domestication, New record, Tripura

\section{INTRODUCTION}

The home gardens are the sites of conservation of a large diversity of plants both wild and domesticated (Das \& Das 2005). Many wild rare species are conserved in the home gardens because of their high commercial value. In Konyak home gardens at Nagaland, forest trees, different bamboo varieties and fruit trees were successfully domesticated and cultivated. Due to significant role of wild plants in the livelihood Konyak tribal people introduced some important species in their home gardens from jhum area (Pradheep et al. 2016). Likewise, Reang tribal peoples have also introduced many important forest plants in their home gardens. In this communication it is reported that the therapeutically important wild plant viz, Stephania glabra (Roxb.) Miers is cultivated in the Reang home gardens in Tripura which is locally known as "blong kha-kchangma" by Reang people.

The genus Stephania Lour. is a climbing shrub distributed in the tropical parts of the world, comprising of 69 species (Hul et al. 2017). However, according to plantlist (Plantlist ver 1.1) there are 40 accepted species of Stephania. In accordance with e-floraofindia, only 10 species are distributed in India. M. Gangopadhyay (Fl. India 1: 332. 1993) reported 8 species and 2 verieties from India. Deb (1983) reported two Stephania species viz, $S$. glandulifera and S. japonica from Tripura. So, the present report on Stephania glabra (Roxb.) Miers is a new distributional record and new addition to Flora of Tripura. Stephania glabra is regarded as endangered in some parts of its range because of its over use as a medicinal plant (Chhetri et al. 2005).

\section{Study Area}

Kanchanpur is the largest subdivision of North Tripura district of Tripura state and situated at the southern side of the district. This subdivision is bounded by Mizoram in the east, 
338 New record and domestication of Stephania glabra in Tripura
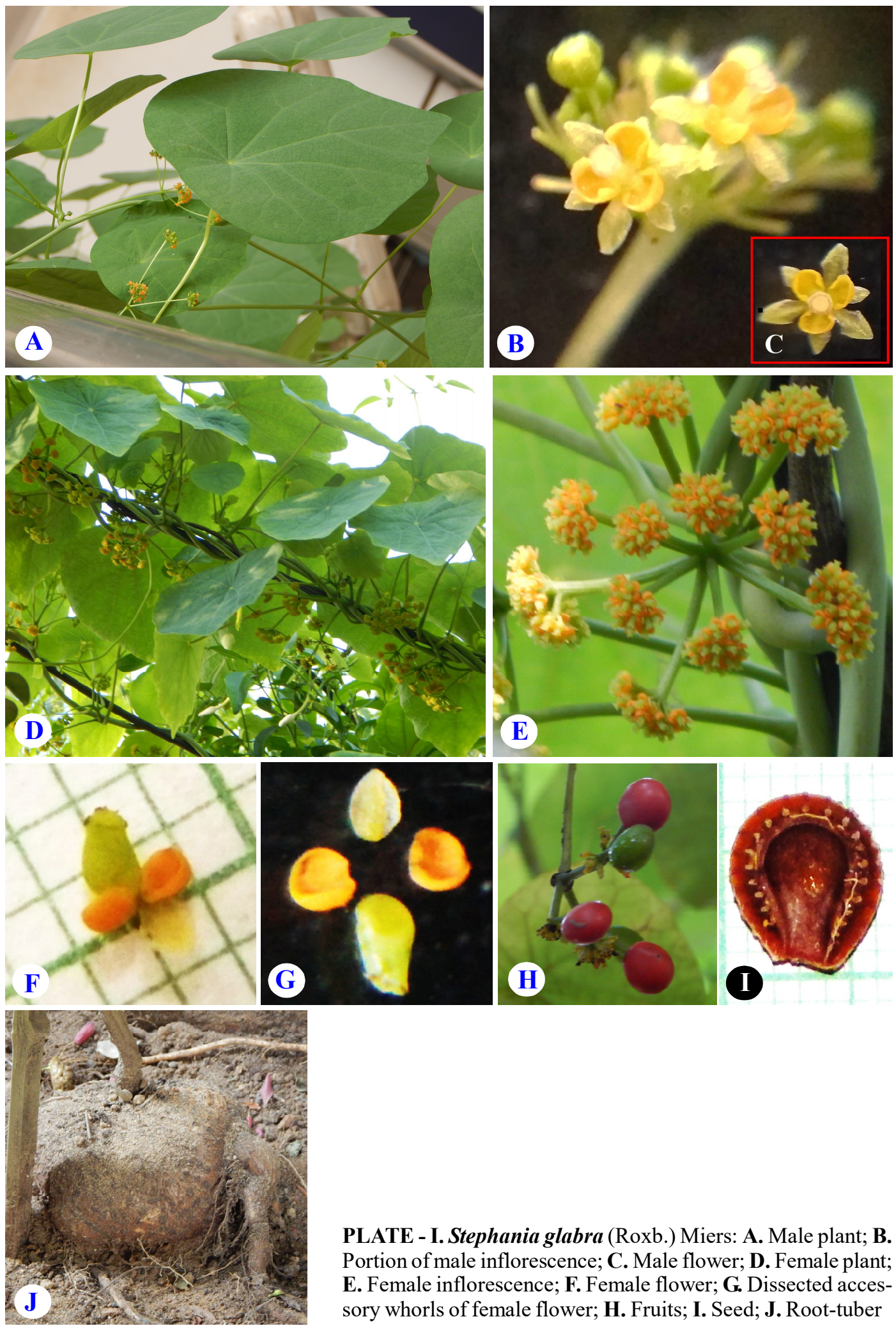

PLATE - I. Stephania glabra (Roxb.) Miers: A. Male plant; B. Portion of male inflorescence; C. Male flower; D. Female plant; E. Female inflorescence; F. Female flower; G. Dissected accessory whorls of female flower; H. Fruits; I. Seed; J. Root-tuber 
Bangladesh in the south, Dhalai and Unakoti district in the west and Panisagar subdivision in the north. River Deo northernly flows through Kanchanpur Valley. Jampui hills range is located in the subdivision. Saboal is a small ADC (Autonomous District Council) village in Jampui hills with mixed population of Lushi and Reang tribe. Bru pada is an ADC village inhabited by only Reang Tribe.

\section{METHODOLOGY}

Extensive field survey was conducted in the study area from October 2015 to December 2016. Specimens of Stephania glabra were collected from Reang Home Gardens at Bru para and root tubers were also collected from road side truncated hills, on the way to Saboal. All the specimens were collected in non-flowering condition. Both the specimens were planted in the author's home garden. Subsequently after flowering plant species have been identified using different literature (Deb 1983), e-floraofindia. Collected specimens were processed into mounted herbarium sheets following standard methods (Jain \& Rao 1977) which have been deposited in Tripura University Herbarium.

\section{TAXONOMIC TREATMENT}

Stephania glabra (Roxb.) Miers in Ann. Mag. Nat. Hist. Ser.3, 18 (103): 14.1866 [Jul 1866] [Syn: Cissampelos glabra Roxb.; Clypea rotunda Steud.; Cocculus finlaysonianus Wall.; Cocculus roxburghianus DC.; Menispermum japonicum Roxb. ex DC.; Menispermum roxburghii Spreng.; Stephania hexandra Miers; Stephania roxburghiana Miers]

Perennial climbing herbaceous shrubs, twining to the left. Roots large tuberous, round or oval greyish.:Stems terete, striate, pubescent, green when young, mature stem grayish. Leaves simple, alternate, rotund, peltate, broadly ovate; petioles $8-20.5 \mathrm{~cm}$ long, petiolar base thickened; lamina $5-12.5 \times 5-13.2 \mathrm{~cm}$, palmately 9-nerved, herbaceous, thinly minute-hairy and white only on lower surface and veins. Male inflorescence compound umbel, axillary; peduncles $4-6 \mathrm{~cm}$ long; Male flowers: pedicels $2 \mathrm{~mm}$; sepals 6 , outer 3 linear-oblong, inner 3 obspathulate, recurved outwardly $1 \times 0.8 \mathrm{~mm}$; petals 3 , obspathulate, orange coloured; synandrium peltate, apex 6 lobed, $1 \times 1 \mathrm{~mm}$. Female flowers: sepal1, up to $1 \mathrm{~mm}$, anterior, pale yellow, $1 \times 0.8 \mathrm{~mm}$; petals $2,1 \times 1 \mathrm{~mm}$, lateral, dark orange; carpel 1, 1 chambered, ovary posteriorly bulged, slightly curved towards sepal, ovule one, $1.5 \times 1 \mathrm{~mm}$, basal; style not differentiated; stigma $4-8$ partite, grooved. Drupes $8 \times 7 \mathrm{~mm}$, roundish flattened; seeds $7 \times 6 \mathrm{~mm}$, endocarp ornamented with rows of more than 20 transverse ridges.

Flowering and fruiting: June - October.

Exsiccate: Tripura: Bru para, 21.08.2016, Das \& Datta TUH 1762 (Tripura University Herbarium).

Distribution: India: Arunachal Pradesh, Assam, Himachal Pradesh, Jharkhand, Madhya Pradesh, Meghalaya, Mizoram, Nagaland, Uttarakhand, Uttar Pradesh, West Bengal; Bangladesh, China, Myanmar, Nepal, Thailand.

Cultivation status: During Home Garden survey at Bru para total 9 households were surveyed, out of which in 5 home gardens Stephania glabra were found to be cultivated and domesticated in large number.

Medicinal use: Reang people apply its leaf-pase on forehead to get relief from headache. 


\section{CONCLUSION}

Home gardens are the important site for plant species domestication. Species domestication in home gardens play very significant role in the conservation of biodiversity. Occurrence of Stephania glabra in Reang home gardens as well as in wild habitats indicate their good conservation status.

\section{Acknowledgements}

Authors are very much grateful to Reang Home Garden owners for allowing us to study and also for sharing their valuable knowledge. They also express their gratitude to N. R. Das (Ex-SDM, Kanchanpur, North Tripura) for logistic support and all other facilities provided during field survey. The first author is thankful to Tripura University for providing research facilities.

\section{LITERATURE CITED}

Chhetri, D.R.; Basnet, D.; Chiu, P.F.; Kalikotay, S.; Chhetri, G. \& Parajuli, S. 2005. Current status of ethnomedicinal plants in the Darjeeling Himalaya. Curr. Sci. 89(2): 265 268.

Das, T. \& Das, A.K. 2005. Inventorying plant diversity in home garden - A case study of Barak valley, Assam, northeast India. Curr. Sci. 89(1): 155 - 163.

Deb, D.B. 1983. The Flora of Tripura State. Vol 2. Today \& Tomorrow's Printers and Publishers, New Delhi.

http://www.efloraofindia/species/m—z/m/menispermaceae/stephania/

http://www.theplantlist.org/1.1/

Hul, S.; Dary, C.; Jacques, F.; Ollivier, E.; Bun, S.S.; Cheng, S.K.; Kim, S.; Peou, Y. \& Jabbour, F. 2017. The world checklist of Stephania (Menispermaceae), with notes on types. Phytotaxa. 298(2): $101-118$.

Jain, S.K. \& Rao, R.R. 1977. A Handbook of Field and Herbarium Methods. Today and Tomorrow's Printers and Publishers, New Delhi.

Pradheep, K.; Soyimchiten.; Pandey, A. \& Bhatt, K.C. 2016. Wild Edible Plants Used by Konyak Tribe In Mon District of Nagaland: Survey and inventorisation. Indian J. Nat. Prod. Resour. 7(1): $74-81$. 